\title{
TOWARDS MORE PRAGMATIC UN PEACE OPERATIONS?
}

DOI: $10.20542 / 2307-1494-2021-2-186-188$

UN Peace Operations in a Changing World Order. Eds. C. de Coning and M.Peter. - Cham: Palgrave Macmillan, 2019. 334 p.

"UN Peace Operations in a Changing World Order" is an edited volume that consists of 15 chapters written by leading academics and practitioners from both the Global South and Global North. Most of them earlier contributed to the 2015 Report of the Independent High-level Panel on Peace Operations convened by former UN Secretary-General Ban Ki-moon to undertake a thorough review of the United Nations peace operations and the emerging needs of the future (the HIPPO report). ${ }^{1}$

This book identifies four major trends in the present world order and explains how they are affecting UN peace operations. The first trend is the North-South rebalancing. The recent rise of the developing countries of the South, led by China, and the growing isolationism of the United States during the Donald Trump presidency signify a transition into a multipolar world order. This trend will challenge the model of global governance dominated by the Global North countries and underrepresenting the interests of the Global South. This imbalance is also reflected in the UN peace operations: while the mandates and the goals of peace operations are determined by the UN Security Council, it is the Global South countries that bear most of the responsibility of contributing troops and the harm arising from those operations. Developing countries are struggling for more political power in setting up international norms and designing peace operations.

The second trend is the rise of regional organizations. When executing their peace operations, the UN frequently finds out that they need to cooperate with regional organizations like the African Union, which has more leverage and legitimacy in Africa. A common criticism towards the UN peace operations is that they are trying to enforce "alien" (Western) norms and practices in the process of peace support and peacebuilding, but ignore local specifics. In those cases, regional organizations are often better qualified and more capable than the United Nations to carry out peace operations.

The third trend is the rise of violent extremism and fundamentalist non-state actors, most notably ISIS in Syria and Iraq, often in weak or failing states. The spread of extremely radical, violent non-state actors creates a new type of armed conflict that requires a special approach from the UN. Among other things, such non-state or quasistate actors often appear more willing to commit war crimes against civilians and crimes against humanity than other types of violent actor. In such cases, the UN peacekeepers are given the mandate to assist the local authority in stabilizing the regime and improving the effectiveness of governance. However, those weak authorities are often unpopular for a reason, and the creeping involvement in state-building impedes the UN's ability to present itself in the peace process as an impartial arbiter.

The fourth trend is that the UN is facing increasing pressure to protect civilians and to adopt a people-centric approach. There are lots of doubts about whether UN peace operations can live up to this expectation as the UN peacekeepers are not equipped with the necessary resource to protect civilians in the midst of an armed conflict. This goal is 
also hard to achieve because sometimes the state itself is the main perpetrator of violence against civilians.

On the basis of these four trends, the book reflects on what challenges do they bring to the UN peace operations and how could such operations better adapt to these challenges. Goals and models of UN peacekeeping are analyzed in broader historical context, starting from the end of World War II to the surge in multi-dimension peace missions after the Cold War and the more robust peace operations of the early $21^{\text {st }}$ century through the present. The so-called "Brahimi Report" ${ }^{2}$ and the above-mentioned 2015 HIPPO report are used as the main reference points that guide the authors' analysis. The key recommendations in these two reports are thoroughly examined in the book. They include: (1) primacy of political missions over military or technological ones; (2) the need to tailor peace operations to each specific case; (3) the UN's expanded partnership with regional organizations; (4) the need to make the UN operations more people-centered.

The authors of the volume's fifteen chapters present a mix of scholars and practitioners - two closely related but often disconnected groups. Policy debates about the UN peace operations are provided in parallel to the discussion over the dramatically changing global context. The book is divided into three parts. The first part talks about the evolving political and strategic context of the UN peacekeeping throughout history, and how they changed the model of peacekeeping at each stage. Different aspects of peacekeeping operations are analyzed, including human security, conflict resolution, and asymmetry in contributions. However, the book shows that the main three principles of peacekeeping: consent of the conflict parties, impartiality, and non-use of force remain resilient and flexible in the face of the changing world order. The second part's focus is on how to meet specific objectives of the UN missions in order to achieve peace and security. The authors address issues such as defining the limits of the use of force, responding to violent extremism, terrorism, and transnational crimes, and the growing demand for UN policing. The third part explores and explains how the UN develops its relationship with other regional actors and how they could contribute to new norms of peacekeeping. The partners examined include the African Union, the European Union, China, and non-state actors. In the concluding chapter, a more pragmatic era of the UN peace operation is predicted. Such operations are likely to become less intrusive and more supportive of locally-led solutions. They would also be less focused on conflict resolution and more centered on conflict management.

This book does a great job to identify major trends in world politics. However, when explaining the implications for the UN peace operations, the contributors mostly elaborate upon recommendations made in the HIPPO report, but overlook the fact that these recommendations, though generally well accepted, are difficult to be implemented. The authors approach world politics and international relations through the lens of liberal institutionalism and construct their arguments on the basis of the assumption that international organizations are independent actors who have their own norms and are able to influence others. When explaining the evolution of peacekeeping operations and exploring possibilities of their future development, the contributors consider the broader geopolitical environment, but fail to even mention which powerful states, including permanent members of the UN Security Council (the P-5), are the driving forces behind many of those changes. While one chapter is dedicated to China's more active role in the UN peacekeeping, the analysis is confined to China's attitude towards peacekeeping principles such as non-intervention and the use of force and fails to dig deeper into Beijing's political interest vested in the UN. After all, as the contributors are fully aware of, the UN peace operations remain an instrument of the Security Council, used in line with 
either the UN Charter's Chapter VI, or Chapter VII. How could the politics of the Security Council be left aside when rethinking the mandates of the UN peace operations?

The main drawback of the wishful thinking that inspired recommendations of the HIPPO report is evident. One of the key recommendations is to overcome the structural separation between peacekeeping operations and special political missions, respectively managed by two different departments of the UN Secretariat: the Department of Peacekeeping Operations and the Department of Political Affairs. This bifurcation leads to a rivalry between the two. When they are assigned to manage the same conflict, the lack of coordination makes their work counterproductive and undermines the process of each other, while better coordination could potentially lead to better results overall. Overcoming this divide would make it possible for the UN to apply a wider spectrum of approaches better tailored to individual cases. Overall, this seems to be a great recommendation that could improve the efficiency of UN peacekeeping. However, in reality, even though the UN Secretary-General took note of it and restructured the peace and security departments to create the new Department of Peace Operations, as suggested by the HIPPO report, the permanent five members of the UN Security Council remain reluctant to bring any large special political missions under the responsibility of this department. The same applies to the idea of creating a single "peace operations account" to finance both peacekeeping operations and special political missions - an idea constantly rejected by the Security Council. No matter what "grand" mission the UN takes up, eventually it is the "great powers" who decide which mission is realistic and they are really mindful of the extent their political power should be delegated to the UN.

That being said, the conclusion of the book remains valid even though the reasoning that led to this conclusion is incomplete. The book provides accurate observations of the main trends in the evolving world order and the challenges and difficulties faced by practitioners in the field. Deep understanding of history and an accurate account of the present provide a sound basis for credible predictions of the future. However, the book largely remains descriptive and fails to incorporate theories that could help explain the ongoing changes and development, and subsequently, strengthen the authors' arguments. This book has done a great job at pointing out the problems and difficulties faced by the UN peace operations, but stops short of providing solutions to them. Positions and interests of the UN Security Council, including the P-5, are taken into consideration, but they are only superficially covered with not elaboration on geopolitical issues and controversies behind them and on how the latter affect the mandates of the UN peace operations. This book does not contribute much new to the UN policy and practice, as its premises are mostly taken from the 2015 HIPPO report and it hardly introduces any new recommendations. Overreliance on the HIPPO recommendations also makes the volume fall prey to the wishful thinking that the UN peace operations have the ability to change and adapt independently from the will of the five permanent numbers of the UN Security Council.

Tailai Jiang (China)

MGIMO-University, Moscow ORCID: 0000-0001-6102-9737

\section{ENDNOTES}

\footnotetext{
${ }^{1}$ Uniting Our Strength for Peace: Politics, Partnership and People. Report of the High-Level Independent Panel on United Nations Peace Operations. 16 June 2015. URL: https://peaceoperationsreview.org/wp-content/ uploads/2015/08/HIPPO_Report_1_June_2015.pdf (accessed 25.11.2021).

2 Report of the Panel on United Nations Peace Operations. UN Doc. A/55/305-S/2000/809. 21 August 2000. https://www.un.org/en/ga/search/view_doc.asp?symbol=A/55/305 (accessed 25.11.2021).
} 